\title{
Efektivitas Penerapan Model Pembelajaran Think Talk Write (TTW) Secara Online Terhadap Literasi Informasi Siswa SMA
}

\author{
I Putu Artayasa*, Tia Fitriani, Baiq Sri Handayani, Kusmiyati \\ Program Studi Pendidikan Biologi, FKIP, Universitas Mataram \\ *Corresponding Author. Email: artayasa75@unram.ac.id
}

\begin{abstract}
This study aims to analyze the effectiveness of the Think Talk Write (TTW) learning model which is carried out online on the information literacy of high school students. This study used a quasi-experimental method with a non-equivalent control group pretest-posttest design. The study was conducted on students of class XI IPA SMA Negeri 1 Labuapi consisting of 36 people. Research data were in the form of information literacy scores obtained from the application of pretest and posttest. The data analysis technique used in this study was covariance analysis (ancova). The results showed that the class that applied TTW learning had an average information literacy posttest score of 3.26 which was higher than the conventional class with an average gain of 2.97. The conclusion is that the application of the TTW learning model is more effective than the conventional learning model in terms of achieving student information literacy.
\end{abstract}

\begin{abstract}
Abstrak: Penelitian ini bertujuan untuk menganalisis efektivitas model pembelajaran Think Talk Write (TTW) yang dilaksanakan secara online terhadap literasi informasi siswa SMA. Penelitian ini menggunakan metode quasi experiment dengan desain pretest-posttest non equivalent control group. Penelitian dilakukan pada siswa kelas XI IPA SMA Negeri 1 Labuapi yang terdiri 36 orang. Data penelitian berupa skor literasi informasi yang diperoleh dari penerapan pretest dan posttest. Teknik analisis data penelitian ini menggunakan analisis kovarian (Anakova). Hasil penelitian menunjukkan bahwa kelas yang menerapkan pembelajaran TTW memiliki rata-rata skor posttest literasi informasi sebesar 3,26 yang lebih tinggi dibandingkan kelas konvensional dengan perolehan rata-rata sebesar 2,97. Kesimpulannya adalah penerapan model pembelajaran TTW memiliki efektivitas yang lebih tinggi dibandingkan penerapan model pembelajaran konvensional dalam hal pencapaian literasi informasi siswa.
\end{abstract}

\section{Article History}

Received: 09-03-2021

Revised: 31-05-2021

Accepted: 26-07-2021

Published: 07-09-2021

\section{Key Words:}

Information Literacy, Think Talk Write, Online Learning.

\section{Sejarah Artikel}

Diterima: 09-03-2021

Direvisi: 31-05-2021

Disetujui: 26-07-2021

Diterbitkan: 07-09-2021

\section{Kata Kunci:}

Literasi Informasi, Think Talk Write, Pembelajaran Daring.

How to Cite: Artayasa, I., Fitriani, T., Handayani, B., \& Kusmiyati, K. (2021). Efektivitas Penerapan Model Pembelajaran Think Talk Write (TTW) Secara Online Terhadap Literasi Informasi Siswa SMA. Jurnal Kependidikan: Jurnal Hasil Penelitian dan Kajian Kepustakaan di Bidang Pendidikan, Pengajaran dan Pembelajaran, 7(3), 641-648. doi:https://doi.org/10.33394/jk.v7i3.3558

This is an open-access article under the CC-BY-SA License.

\section{Pendahuluan}

Penerapan pembelajaran pada masa pandemi Coronavirus Disease 2019 (Covid-19) berdampak signifikan terhadap model pelaksanaan pembelajaran di sekolah. Selama masa darurat Covid-19, pembelajaran dilaksanakan secara online untuk mengurangi potensi munculnya kerumunan di sekolah sehingga dapat mengurangi laju penyebaran virus corona tersebut. Pembelajaran online memungkinkan guru membagikan materi ajar berupa slide power point, video pembelajaran dan lain-lain sehingga tetap dapat memfasilitasi siswa belajar. (Abidin et al., 2020). Penerapan pembelajaran online memungkinkan siswa mengikuti proses pembelajaran dari rumah masing-masing, walaupun pembelajaran ini 
seringkali terkendala oleh kurangnya ketersediaan layanan internet disamping kendala biaya (Firman \& Rahman, 2020).

Pembelajaran online atau daring merupakan perubahan pembelajaran konvensional ke arah bentuk digital sehingga terdapat peluang disamping tantangan terhadap upaya meningkatkan literasi siswa (Harjanto \& Sumunar, 2018). Memasuki abad XXI siswa dihadapkan pada tuntutan untuk memiliki literasi dasar terutama literasi informasi. Menurut Riski et al. (2018), literasi informasi adalah kemampuan yang harus dimiliki oleh semua orang khususnya pelajar karena dalam kegiatan belajar mengajar siswa diterpa oleh banyak informasi dari berbagai sumber informasi sehingga mereka harus dapat menyeleksi informasi yang benar.

Siswa membutuhkan informasi menyesuaikan lingkungan akademiknya yang berbeda dengan kalangan lainnya (Amellia, 2015). Banyaknya informasi yang tersedia pada berbagai media saat ini belum menjamin seseorang mampu mencari, menggunakan, mengevaluasi dan memanfaatkan informasi tersebut secara efektif. Dimilikinya banyak informasi bukan berarti semua kebutuhan akan informasi terpenuhi. Hal ini disebabkan karena informasi yang didapat belum tentu sesuai dengan yang dibutuhkan karena banyak diantaranya tidak dapat dipertanggungjawabkan kebenarannya. Dengan demikian, kemampuan literasi informasi siswa sangat penting ditingkatkan. Peningkatan literasi informasi berperan untuk membangun kemampuan siswa dalam mencari, menganalisis dan memanfaatkan informasi guna menyelesaikan tugas di sekolah.

Observasi yang telah dilakukan di SMA Negeri 1 Labuapi Kabupaten Lombok Barat Provinsi Nusa Tenggara Barat pada semester ganjil tahun ajaran 2020/2021 kelas XI IPA menunjukkan bahwa hasil belajar Biologi siswa masih rendah. Berdasarkan buku penilaian pengetahuan dan keterampilan siswa, rata-rata nilai tes formatif pada materi sel dan jaringan makhluk hidup berturut-turut adalah 63 dan 56. Rata-rata nilai ini menunjukkan masih berada di bawah Kriteria Ketuntasan Minimal sebesar 75. Hasil observasi terhadap hasil tes formatif tersebut mengindikasikan bahwa literasi informasi siswa selama penerapan metode konvensional selama belajar dari rumah pada kondisi pandemi Covid-19 masih kurang. Hal ini karena tingkat literasi informasi siswa dapat direfleksikan dari besarnya prestasi belajar siswa. Menurut Kusunarningsih (2018), literasi informasi memberikan kontribusi terhadap prestasi belajar sebesar 61,9\%. Literasi informasi menyebabkan siswa dapat memilih dan memanfaat informasi untuk pemecahan masalah dengan tepat dan kesuksesan dalam belajar (Himawan, 2014; Pattah, 2014).

Berdasarkan permasalahan yang ditemui di SMA Negeri 1 Labuapi tersebut, perlu dilakukan perbaikan dan pemilihan model pembelajaran untuk meningkatkan literasi informasi siswa. Model pembelajaran yang dipilih berupaya menyebabkan siswa tetap aktif belajar dengan mencari informasi terkait materi pembelajaran meskipun pembelajaran dilakukan secara online dari rumah. Pembelajaran dengan mendorong pencarian informasi secara masif akan menumbuhkan pengetahuan yang dapat berefek terhadap peningkatan hasil belajar siswa. Salah satu model pembelajaran yang menyebabkan siswa aktif dalam mencari dan menyebarkan informasi terkait pembelajaran adalah model pembelajaran Think Talk Write (TTW). Menurut Armini et al. (2017), penerapan model pembelajaran TTW mendorong siswa mengkomunikasikan hasil belajarnya. Pendapat senada dikemukakan Suparya (2018) bahwa model pembelajaran TTW adalah pembelajaran yang mengimplementasikan proses berpikir, berbicara, dan menulis. Pemberian kesempatan siswa untuk berpikir, berbicara dan menulis terkait materi yang dipelajari akan berpengaruh terhadap literasi informasi siswa. Menurut Mubaroq et al. (2018), literasi informasi merupakan dasar dari kegiatan berpikir dan melakukan sesuatu dalam kehidupan, sehingga 
literasi informasi sangat penting bagi setiap orang. Dengan demikian, penelitian bertujuan untuk menganalisis efektivitas model pembelajaran TTW yang diterapkan secara online terhadap literasi informasi siswa di SMA Negeri 1 Labuapi penting dilakukan. Dimilikinya literasi informasi yang baik akan berdampak terhadap kemampuan belajar siswa yang pada akhirnya dapat berkontribusi terhadap peningkatan prestasi belajar siswa.

\section{Metode Penelitian}

Penelitian ini menggunakan metode kuasi eksperimen dengan desain pretest-posttest non equivalent control group dilaksanakan di SMA Negeri 1 Labuapi pada semester ganjil tahun ajaran 2020/2021. Populasi penelitian adalah semua siswa kelas XI IPA yang terdiri 36 orang yang terdistribusi menjadi 17 siswa untuk kelas eksperimen dan 19 siswa untuk kelas kontrol. Data penelitian berupa skor pretest dan posttest literasi informasi. Instrumen pengumpul data berupa kuesioner. Pernyataan literasi informasi pada kuesioner disusun dengan mengadopsi kaidah-kaidah literasi informasi dari Suryadi (2019). Jenis kuesioner yang di aplikasikan adalah kuesioner tertutup dalam bentuk pernyataan positif dengan pilihan jawaban dalam bentuk skala Likert 1-4 (Tabel 1). Kuesioner dibagikan pada link google form, kemudian siswa diminta untuk memilih salah satu pilihan jawaban yang sesuai dengan apa yang dialami dan dirasakan siswa. Pengujian hipotesis dilakukan dengan Anakova dan pengolahan data dilakukan dengan bantuan paket pengolahan data SPSS 17.0.

Tabel 1. Pernyataan pada Kuesioner Literasi Informasi

\begin{tabular}{|c|c|c|c|c|c|}
\hline \multirow{2}{*}{$\begin{array}{l}\text { Model Literasi } \\
\text { Informasi }\end{array}$} & \multirow{2}{*}{ Pernyataan } & \multicolumn{4}{|c|}{ Kategori } \\
\hline & & STS & $\mathrm{TS}$ & $\mathrm{S}$ & SS \\
\hline \multirow[t]{17}{*}{ Empowering 8} & Identifikasi & & & & \\
\hline & $\begin{array}{l}\text { 1. Saya dapat menjelaskan dengan mudah topik sendiri } \\
\text { tanpa dibantu guru menjelaskannya }\end{array}$ & 1 & 2 & 3 & 4 \\
\hline & 2. Saya bisa menentukan sasaran makalah yang saya buat & 1 & 2 & 3 & 4 \\
\hline & 3. Saya memahami format penyusunan makalah yang benar & 1 & 2 & 3 & 4 \\
\hline & $\begin{array}{l}\text { 4. Saya bisa mengidentifikasi kata kunci untuk } \\
\text { memudahkan pencarian informasi sesuai dengan topik } \\
\text { makalah }\end{array}$ & 1 & 2 & 3 & 4 \\
\hline & $\begin{array}{l}\text { 5. Saya menggunakan buku dan internet dalam menelusuri } \\
\text { informasi }\end{array}$ & 1 & 2 & 3 & 4 \\
\hline & $\begin{array}{l}\text { 6. Disamping buku dan internet, saya memanfaatkan kamus, } \\
\text { majalah, koran, serta lingkungan sekitar sebagai sumber } \\
\text { informasi }\end{array}$ & 1 & 2 & 3 & 4 \\
\hline & Organisasi & & & & \\
\hline & $\begin{array}{l}\text { 7. Saya bisa memilih informasi yang selaras dengan } \\
\text { kebutuhan saya }\end{array}$ & 1 & 2 & 3 & 4 \\
\hline & $\begin{array}{l}\text { 8. Saya bisa mengidentifikasi informasi berupa fakta, } \\
\text { pendapat, dan khayalan }\end{array}$ & 1 & 2 & 3 & 4 \\
\hline & 9. Saya bisa mengidentifikasi informasi yang akurat & 1 & 2 & 3 & 4 \\
\hline & 10. Saya bisa membuat urutan informasi yang logis & 1 & 2 & 3 & 4 \\
\hline & $\begin{array}{l}\text { 11. Saya memahami informasi berupa gambar (diagram, } \\
\text { struktur, ilustrasi) serta dapat memilah informasi yang } \\
\text { lebih relevan untuk digunakan. }\end{array}$ & 1 & 2 & 3 & 4 \\
\hline & Menciptakan & & & & \\
\hline & 12. Saya menuliskan pendapat saya sendiri dalam makalah & 1 & 2 & 3 & 4 \\
\hline & $\begin{array}{l}\text { 13. Saya merevisi dan mengedit makalah sendiri atau } \\
\text { meminta bantuan teman }\end{array}$ & 1 & 2 & 3 & 4 \\
\hline & $\begin{array}{l}\text { 14. Saya menyusun daftar rujukan berdasarkan sumber } \\
\text { informasi yang saya manfaatkan }\end{array}$ & 1 & 2 & 3 & 4 \\
\hline
\end{tabular}




\section{Hasil Penelitian dan Pembahasan}

Hasil penelitian ini dijelaskan dari data pretest dan posttest literasi informasi siswa kelas XI IPA SMA Negeri 1 Labuapi. Data literasi informasi tersebut adalah rata-rata skor pretest siswa kelas eksperimen adalah 2,96 sementara rata-rata skor kelas kontrol adalah 2,93. Rata-rata skor posttest literasi informasi siswa kelas eksperimen adalah 3,26 sementara kelas kontrol memiliki rata-rata posttest yang lebih rendah yaitu sebesar 2,97. Ringkasan hasil pretest dan posttest tersebut terdapat pada Gambar 1 berikut ini.

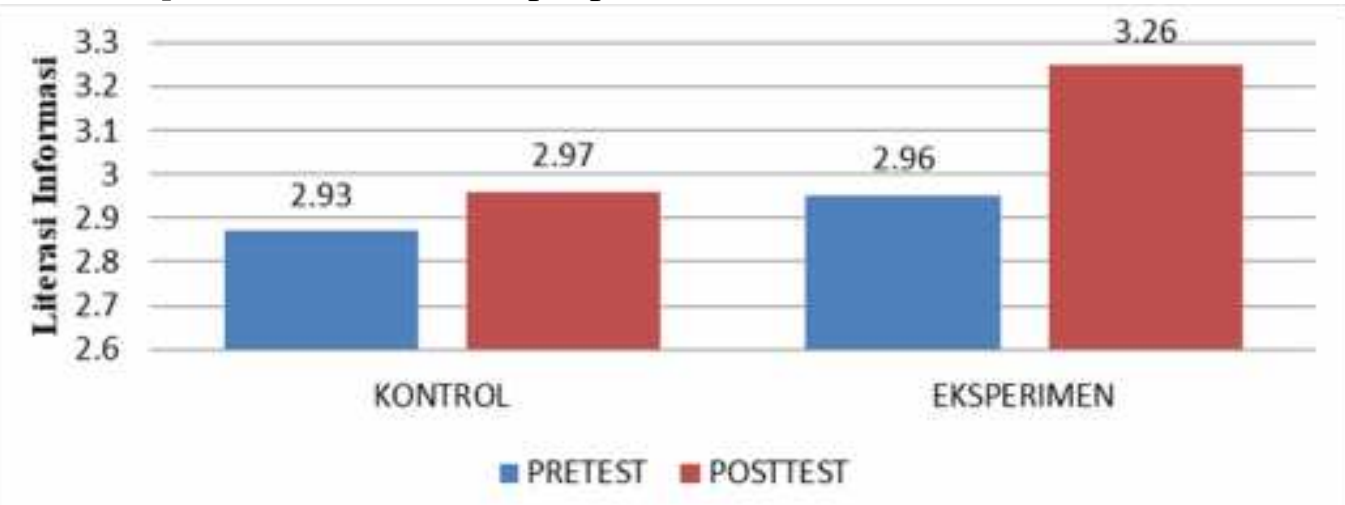

Gambar 1. Rata-rata Skor Literasi Informasi Siswa Kelas Eksperimen dan Kontrol Hasil Uji normalitas data didasarkan hasil uji Kolmogorov-Smirnov menunjukkan bahwa baik data pretest maupun posttest literasi informasi pada kelas eksperimen dan kelas kontrol berdistribusi normal yang ditandai dengan nilai sig. atau $p>0,05$. Rangkuman hasil uji normalitas tersebut ditunjukkan pada Tabel 2.

Tabel 2. Hasil Uji Normalitas

\begin{tabular}{|c|c|c|c|c|c|c|}
\hline & \multirow{2}{*}{ Kelas } & \multicolumn{5}{|c|}{ Kolmogorov-Smirnov $^{\mathrm{a}}$} \\
\hline & & Statistik & df & Sig. $(p)$ & Alpha & Ket. \\
\hline & Pretest Eksperimen & .120 & 17 & .200 & 0,05 & Normal \\
\hline Literasi & Posttest Eksperimen & .138 & 17 & .200 & 0,05 & Normal \\
\hline \multirow[t]{2}{*}{ Informasi } & Pretest Kontrol & .176 & 19 & .122 & 0,05 & Normal \\
\hline & Posttest Kontrol & .150 & 19 & .200 & 0,05 & Normal \\
\hline
\end{tabular}

Sementara itu hasil uji homogenitas berdasarkan uji levene's mengisyaratkan bahwa data pretest dan posttest literasi informasi mempunyai varians yang homogen. Homogenitas data tersebut ditunjukkan dari nilai signifikansi atau $p>0,05$. Hasil uji homogenitas data ditampilkan pada Tabel 3.

Tabel 3. Ringkasan Hasil Uji Homogenitas Literasi Informasi

\begin{tabular}{|c|c|c|c|c|c|c|c|}
\hline & & $\mathrm{F}$ & $\mathrm{df} 1$ & df2 & Sig. $(p)$ & Alpha & Ket. \\
\hline Literasi & Pretest & .010 & 1 & 34 & .921 & 0,05 & Homogen \\
\hline Informasi & Posttest & .261 & 1 & 34 & .613 & 0,05 & Homogen \\
\hline
\end{tabular}

Uji hipotesis dilakukan melalui analisis kovarian (Anakova). Berdasarkan analisis kovarian menggunakan bantuan aplikasi SPSS 17.0 diperoleh data rata-rata literasi informasi posttest terkoreksi pretest (Estimated Marginal Mean). Hasil uji Anakova ditunjukkan pada Tabel 4.

Tabel 4. Rata-Rata Posttest Terkoreksi Pretest

\begin{tabular}{cccrrrr}
\hline & Kelompok & Pretest & Posttest & $\begin{array}{c}\text { Rata-Rata } \\
\text { Terkoreksi }\end{array}$ & Notasi \\
\hline Literasi & Eksperimen & 2.9578 & 3.2567 & 3.255 & a & \\
Informasi & Kontrol & 2.9311 & 2.9667 & 2.968 & b
\end{tabular}

Rata-rata skor posttest literasi informasi pada kelas eksperimen sebesar 3,26 (notasi a) yang lebih tinggi dari rata-rata pada kelas kontrol dengan skor 2.97 (notasi b). Berdasarkan analisis 
kovarian pada alpha 0,05 menunjukkan adanya perbedaan yang signifikan pada rata-rata skor posttest terkoreksi antara kelas eksperimen dan kelas kontrol. Hasil uji Anakova tersaji pada Tabel 4 dan 5.

Tabel 5. Hasil Analisis Kovarian

\begin{tabular}{cccccccc}
\hline & Source & $\begin{array}{c}\text { Type III Sum of } \\
\text { Squares }\end{array}$ & df & Mean Square & F & $\begin{array}{c}\text { Sig. } \\
(p)\end{array}$ & $\begin{array}{c}\text { Partial Eta } \\
\text { Squared }\end{array}$ \\
\hline \multirow{4}{*}{ Lorrected Model } & 85.834 & 2 & 42.917 & 4.27 & .022 & .206 \\
Literasi & Intercept & 379.345 & 1 & 379.345 & 37.7 & .000 & .534 \\
Informasi & Pretest & .179 & 1 & .179 & .018 & .895 & .001 \\
& Kelompok & & & & & & \\
(Perlakuan) & 81.918 & 1 & 81.918 & 8.15 & .007 & .198 \\
& Error & 331.388 & 33 & 10.042 & & & \\
& Total & 28084.00 & 36 & & & & \\
& Corrected Total & 417.222 & 35 & & & & \\
\hline
\end{tabular}

Berdasarkan analisis kovarian, pada pretest diperoleh nilai $\mathrm{F}=0,018$ dan nilai signifikan $(p)$ $=0,895$, artinya nilai tersebut lebih besar dari alpha 0,05 , sehingga hasil uji tersebut mengindikasikan bahwa skor pretest tidak berpengaruh signifikan artinya tidak ada hubungan linear dengan skor posttest literasi informasi siswa. Sementara itu, hasil analisis perbedaan kelompok (perlakuan) menunjukkan nilai $\mathrm{F}=8,15$, dengan nilai $p=0,007$ atau nilai $p<0,05$ artinya pemberian perlakukan berpengaruh signifikan terhadap skor literasi informasi. Dengan kata lain, penerapan model pembelajaran TTW lebih efektif dari pada penerapan model pembelajaran konvensional terhadap literasi informasi siswa yang direfleksikan dari skor literasi informasi kelas yang menerapkan pembelajaran TTW lebih tinggi secara signifikan dibandingkan skor kelas konvensional.

Hasil temuan ini mengindikasikan bahwa implementasi model pembelajaran TTW berdampak positif terhadap peningkatan literasi informasi siswa. Temuan penelitian ini sejalan dengan temuan penelitian Tauhidah et al. (2017) bahwa penerapan model pembelajaran TTW berkontribusi meningkatkan kemampuan literasi informasi siswa. Temuan penelitian ini juga senada dengan pendapat Putriani et al. (2017) bahwa penggunaan model TTW dalam pembelajaran literasi akan berkontribusi meningkatkan kemampuan siswa berliterasi secara baik.

Kemampuan literasi informasi siswa yang meningkat signifikan pada kelas eksperimen adalah kontribusi dari penerapan model TTW yang memberikan kesempatan siswa untuk mendapatkan informasi yang relevan, dapat dipercaya, serta valid melalui upaya penelusuran berbagai sumber informasi baik melalui internet, buku ajar, dan sumber belajar lainnya. Dalam pembelajaran TTW, siswa didorong untuk terus mencari dan memanfaatkan informasi guna menyelesaikan tugas penyusunan makalah yang menjadi kegiatan pokok dari penerapan model pembelajaran TTW. Kemampuan seseorang untuk mengidentifikasi, menemukan, mengevaluasi, menggunakan informasi untuk pemecahan masalah serta mengkomunikasikan informasi kepada orang lain dengan baik dapat dikatakan seseorang tersebut mempunyai literasi informasi yang baik (Iskandar, 2016).

Peningkatan literasi informasi siswa kelas eksperimen dapat dikaitkan dengan dampak dari setiap tahapan kegiatan model pembelajaran TTW. Model pembelajaran TTW dilaksanakan dalam tiga tahap yakni Think, Talk dan Write. Kegiatan think berdampak pada pemberian kesempatan siswa untuk membaca, mengolah, dan memanfaatkan berbagai informasi. Pemberian kesempatan siswa untuk mencari banyak sumber bacaan dan memikirkan kebermanfaatannya akan dapat meningkatkan kemampuan, keterampilan, dan 
wawasan siswa tentang informasi yang dipilihnya (Suwanto, 2015). Lebih jauh dikatakan Suwanto (2015) bahwa kemampuan mencari dan memanfaat informasi tersebut merupakan bekal untuk mengembangkan diri dalam kegiatan belajar dan bekerja.

Kegiatan kedua dari penerapan model TTW adalah talk (berbicara atau berdiskusi). Kegiatan yang kedua ini berupa diskusi siswa dalam kelompoknya sehingga dapat berkontribusi meningkatkan kemampuan siswa untuk bertukar informasi. Kegiatan untuk bertukar informasi tersebut dapat memfasilitasi siswa melatih keterampilan berkomunikasi dengan baik. Menurut Ilhamdi dan Mertha (2020) pembelajaran dengan melakukan investigasi berkelompok menyebabkan ketertarikan siswa belajar lebih tinggi, pembelajaran lebih bermakna, dan meningkatkan kemampuan komunikasi siswa. Dimilikinya kemampuan berkomunikasi secara efektif mengindikasikan seseorang memiliki literasi informasi yang baik.

Kegiatan yang ketiga pada penerapan model TTW adalah write (menulis). Kegiatan ini memberikan dukungan kemampuan menulis hasil literasi informasi siswa. Menurut Tauhidah (2017), model pembelajaran TTW dapat meningkatkan keterampilan menulis secara signifikan. Menulis adalah muara dari kegiatan membaca, mengevaluasi dan memanfaatkan informasi, dengan demikian, kegiatan pembelajaran yang memfasilitasi siswa banyak menulis dapat berdampak terhadap pengembangan literasi informasinya. Menurut Cahyadi (2018), kemampuan menulis berkorelasi kuat dengan literasi informasi, karena seseorang yang literat dalam menulis akan memiliki kemampuan mengenali kebutuhan informasi, mengevaluasi informasi dengan baik, dan menciptakan pengetahuan baru dengan informasi yang dimilikinya. Lebih jauh dikatakan Suarny dan Jumino (2019) bahwa upaya meningkatkan literasi informasi dilakukan dengan mengeksplorasi dan menyusun informasi dalam karya tulis.

Penerapan model TTW dalam penelitian ini dilakukan melalui pembelajaran online, sehingga memberikan tantangan yang berbeda dan lebih tinggi dibandingkan pembelajaran TTW yang biasanya dilakukan secara offline. Penerapan model TTW secara online memungkinkan siswa melakukan kegiatan asinkronus sehingga mereka lebih leluasa dalam mencari dan memilah informasi yang bermanfaat. Pembelajaran jarak jauh yang dilakukan melalui online dapat mengembangkan kemandirian belajar serta meningkatkan tantangan mencari informasi sehingga meningkatkan literasi informasi siswa. Hal ini sesuai dengan pendapat Firman dan Rahman (2020), belajar secara lebih mandiri atau tanpa bimbingan langsung guru akan memacu siswa mencari berbagai informasi yang relevan dengan materi pembelajaran serta tugas-tugas rumah yang harus dikerjakan siswa. Pemberian kesempatan siswa untuk mencari informasi secara mandiri akan berdampak positif terhadap pengembangan literasi informasi dan siswa menjadi berpikir kritis dan logis serta tidak mudah percaya dengan informasi yang didapat (Suwanto, 2015; Silvana et al., 2017).

\section{Kesimpulan}

Kesimpulan penelitian ini adalah terdapat perbedaan efektivitas antara model pembelajaran TTW yang dilaksanakan secara online dan model pembelajaran konvensional terhadap literasi informasi siswa dari SMA Negeri 1 Labuapi. Model pembelajaran TTW memiliki efektivitas yang lebih tinggi daripada pembelajaran konvensional yang ditandai rata rata skor literasi informasi siswa yang menerapkan pembelajaran TTW secara online sebesar 3,26 yang lebih tinggi secara signifikan dari skor siswa kelas konvensional dengan rata-rata 2,96. 


\section{Saran}

Berdasarkan kesimpulan penelitian tersebut, guru disarankan mengintegrasikan model pembelajaran TTW dengan topik-topik yang membahas materi yang terkait dengan permasalahan kehidupan sehari-hari siswa. Topik pembelajaran yang terkait dengan kehidupan sehari-hari siswa umumnya menjadi daya tarik siswa untuk memikirkannya (think), membicarakannya (talk), dan menulisnya (write) meskipun pembelajaran dilakukan dari rumah secara online. Siswa perlu terus mengupayakan peningkatan literasi informasinya melalui kegiatan membaca, berdiskusi dan menulis.

\section{Daftar Pustaka}

Abidin, Z., Rumansyah., \& Arizona, K. (2020). Pembelajaran Online Berbasis Proyek Salah Satu Solusi Kegiatan Belajar Mengajar di Tengah Pandemi Covid-19. Jurnal Ilmiah Profesi Guru, 5(1), 64-70.

Amellia, K. (2015). Efektivitas Penggunaan Model Discovery Learning Terhadap Peningkatan Kemampuan Literasi Informasi. Skripsi. Universitas Pendidikan Indonesia.

Armini, N. P S., Wibawa, I. M. C., \& Murda, I N. (2017). Pengaruh Model Pembelajaran Think Talk Write Terhadap Hasil Belajar IPA Pada Siswa Kelas IV SD. E-Journal PGSD Universitas Pendidikan Ganesha Mimbar PGSD, 5(2), 1-10.

Cahyadi, D. A. (2018). Kemampuan Literasi Informasi Peneliti Dalam Penulisan Karya Ilmiah di Loka Litbangkes Pangandaran. Jurnal Kajian Informasi dan Perpustakaan, 6(2), 139-150. doi: https://dx.doi.org/10.24198/jkip.v6i2.17774

Firman, \& Rahman, S R. (2020). Pembelajaran Online di Tengah Pandemi Covid-19. Indonesian Journal of Education Science, 2(2), 81-89.

Harjanto, T., \& Sumunar, D. S. E. W. (2018). Tantangan Dan Peluang Pembelajaran Dalam Jaringan: Studi Kasus Implementasi Elok (E-Learning: Open For Knowledge Sharing) Pada Mahasiswa Profesi Ners. Jurnal Keperawatan Respati Yogyakarta, 5, 24-28.

Himawan, D. (2014). Pengantar Literasi Informasi: Pelatihan Literasi Informasi di Perpustakaan Institut Pertanian Bogor. Diakses 25 Juli 2020 dari https://repository.ipb.ac.id/jspui/bitstream/123456789/81255/2/LITERASI\%20INFO RMASI\%20PENGANTAR.pdf.

Ilhamdi, M. L., \& Mertha, I.G. (2020). Penerapan Model Pembelajaran Kooperatif Tipe Investigasi Kelompok dalam Pembelajaran Biologi Umum. Jurnal Pijar MIPA,15(1), 20-26.

Iskandar. (2016). Literasi Informasi: Perspektif Pustakawan. JUPITER, 15(1), 10-15.

Kusunarningsih, S. (2018). Hubungan Antara Kompetensi Literasi Informasi dengan Kemampuan Menulis dengan Prestasi Belajar Mahasiswa Universitas Airlangga. Diakses 05 Maret 2021 dari http://repository.unair.ac.id/74754/3/JURNAL_Fis.IIP $.34 \% 2018 \% 20 \mathrm{Kus} \% 20 \mathrm{~h} . \mathrm{pdf}$

Mubaroq, R A., Handhika, J., \& Huriawati, F. (2018). Peran Pendidik dan Ilmuwan Sains Dalam Menyongsong Revolusi Industri 4.0. Universitas PGRI Madiun. Diakses 02 Desember 2019 dari http://E-Journal.Unipma.Ac.Id/Index. Php/Snpf.

Pattah, S. H. (2014). Literasi informasi: Peningkatan kompetensi informasi dalam proses pembelajaran. Jurnal Ilmu Perpustakaan dan Kearsipan Khizanah Al=Hikmah, 2(2), 117-128.

Putriani, I., Suwignyo, H., \& Hasanah, M. (2017). Pembelajaran Literasi pada Siswa Sekolah Dasar Melalui Strategi Think Talk Write (TTW). Transformasi Pendidikan Abad 21(6), 715-720. 
Riski, L, Winoto, Y., \& Asep Saeful Rohman, A.S. (2018). Literasi Informasi Siswa Sekolah Menengah Pertama dalam Pengerjaan Tugas Sekolah. Bibliotika: Jurnal Kajian Perpustakaan dan Informasi, 2(2), 132-140.

Silvana,T., Fitriawati, \& Saepudin, E. (2017). Studi Tentang Kemampuan Literasi Informasi Di Kalangan Siswa Menengah Pertama, Ejournal.UPI, 7(2), 17-28. Diakses 03 Maret 2021 dari https://ejournal.upi.edu/index.php/edulib/article/download/9488/5876

Suarny, L \& Jumino. (2019). Literasi Informasi Mahasiswa Dalam Penulisan Sitiran Karya Tulis Ilmiah: Studi Kasus Unit Pelaksana Kegiatan Research Incubator Centre Fakultas Sains dan Matematika Universitas Diponegoro. Diakses 05 Maret 2021 dari https://ejournal3.undip.ac.id/index.php/jip/article/download/23178/21203

Suparya. (2018). Pengaruh Model Pembelajaran Kooperatif Tipe Think Talk Write (TTW) Terhadap Hasil Belajar Dan Kemampuan Berpikir Kritis Pada Pembelajaran IPA Di Sekolah Dasar. Widyacarya. 2(2), 19-24.

Suryadi, D. (2019). Pengenalan Joho Literasi. Universitas Muhammadiyah Yogyakarta, Indonesia: LP3M.

Suwanto, S. A. (2015). Analisis Literasi Informasi Pemakai Taman Bacaan Masyarakat, Jurnal Kajian Informasi dan Perpustakaan, 3(1), 89-100

Tauhidah, D., Amalina, N. S., \& Suwono, H. (2017). Peningkatan Literasi informasi dan Keterampilan Menulis Melalui Penerapan Model Think Talk Write (TTW) pada Mahasiswa Pendidikan Biologi Mata Kuliah Metodologi Penelitian di Universitas Negeri Malang. Prosiding Nasional Hayati V, Malang, Indonesia: Universitas Negeri Malang. 